\title{
Characteristics of carbonic anhydrase 9 expressing cells in human intestinal crypt base
}

\author{
HIDEKAZU TAKAHASHI ${ }^{1,2^{*}}$, YOZO SUZUKI ${ }^{1,3^{*}}$, JUNICHI NISHIMURA ${ }^{1}$, NAOTSUGU HARAGUCHI ${ }^{1,4}$, \\ MASAHISA OHTSUKA ${ }^{1,5}$, SUSUMU MIYAZAKI $^{6}$, MAMORU UEMURA ${ }^{1}$, TAISHI HATA ${ }^{1}$, ICHIRO TAKEMASA ${ }^{1}$, \\ TSUNEKAZU MIZUSHIMA ${ }^{1}$, HIROFUMI YAMAMOTO ${ }^{1}$, YUICHIRO DOKI $^{1}$ and MASAKI MORI ${ }^{1}$ \\ ${ }^{1}$ Department of Gastroenterological Surgery, Graduate School of Medicine, Osaka University, Osaka 565-0871; \\ ${ }^{2}$ Department of Surgery, Itami City Hospital, Itami, Hyogo 664-8540, Japan; ${ }^{3}$ Department of Medical Oncology, \\ Dana-Farber Cancer Institute, Harvard Medical School, Boston, MA 02215, USA; ${ }^{4}$ Department of Surgery, \\ National Hospital Organization Osaka National Hospital, Chuo-Ku, Osaka 540-0006, Japan; \\ ${ }^{5}$ Department of Experimental Therapeutics, The University of Texas MD Anderson Cancer Center, Houston, TX 77054, USA; \\ ${ }^{6}$ Department of Surgery, Osaka General Medical Center, Higashi Sumiyoshi-Ku, Osaka 558-0056, Japan
}

Received September 1, 2015; Accepted October 22, 2015

DOI: $10.3892 /$ ijo.2015.3260

\begin{abstract}
Though recent studies have revealed that stem cells of many tissues are harbored in hypoxic microenvironment, little is known about the relationship between hypoxia and intestinal crypt base, where intestinal stem cells are supposed to exist. In this study, we focused on carbonic anhydrase IX (CA9), a hypoxia-inducible membrane-tethered protein, in normal intestinal crypt base, adenoma and early colorectal cancer. Using surgically resected human colorectal cancer specimen, we searched for the expression pattern and functional association of CA9 in human adult normal intestinal epithelia, adenoma and early colorectal cancer by immunofluorescent and immunohistochemical staining, flow cytometry, and quantitative real-time-polymerase chain reaction. We demonstrated that almost all crypt base slender cells in ileum and crypt base cells with eosinophilic structure in their basal cytoplasm in right and left colon were $\mathrm{CA}^{+}{ }^{+}$with the ratio of 25 to $40 \%$, and that adenoma and T1 colorectal cancer showed broad expression of CA9. Flow cytometrically sorted CA9 ${ }^{+}$population showed increased mRNA level of a Wnt signaling factor $A X I N 2$. In conclusion, these observations indicate that CA9 expression in normal crypt base cells has association with intestinal epithelial stemness and CA9 may be involved in the carcinogenesis of colorectal cancer.
\end{abstract}

Correspondence to: Dr Junichi Nishimura, Department of Gastroenterological Surgery, Graduate School of Medicine, Osaka University, 2-2 Yamadaoka, Suita, Osaka 565-0871, Japan

E-mail: jnishimura@gesurg.med.osaka-u.ac.jp

${ }^{*}$ Contributed equally

Key words: intestinal epithelial crypt base, carbonic anhydrase IX, hypoxia, $A X I N 2$, colorectal cancer

\section{Introduction}

Vigorous research has shown that the intestinal epithelial stem cells are located at the bottom of the crypt base (1) and consist of proliferative and quiescent types. It is widely accepted that the proliferative stem cells are crypt base columnar (CBC) cells and are positive for the leucine-rich repeat-containing G-protein-coupled receptor 5 (Lgr5) (2) and that quiescent stem cells are located at +4 position from the bottom of the crypt base (3) and positive for Bmi-1 (4), Hopx (5), mTert (6) and Lrig1 (7). The intestinal stem cells are thought to be supported by their adjacent Paneth cells in small intestine (8) through Wnt (9), Notch (10) and epidermal growth factor (EGF) (11) signaling and adversely influenced by villus cells through bone morphogenetic protein (BMP) signaling (12).

Carbonic anhydrase 9 (CA9) is a membrane-bound isozyme of 12 enzymatically active CAs in human, and catalyzes the reversible reaction between carbon dioxide $\left(\mathrm{CO}_{2}\right)$ and water to the bicarbonate ion and protons at its extracellular catalytic site. High expression of CA9 has been reported in limited cell types of normal tissues $(13,14)$ and the relationship between CA9 and advanced status of cancer has been intensely studied (15-19). However, CA9 expression in normal human intestinal epithelial cells and early stage colorectal cancer (CRC) remains incompletely understood.

In this study, we assessed the characteristics and distribution pattern of CA9 positive cells in human intestinal epithelial cells using clinical samples and in T1 CRC.

\section{Materials and methods}

Tissue samples. Surgically resected human adult intestinal normal tissues and T1 CRC tissues were obtained from 20 patients with CRC ( 2 cecum, 5 ascending, 2 transverse, 3 descending, 5 sigmoid colon, 3 rectum; 54 to 84 years old, 
Table I. Primer sequences and TaqMan probes used for quantitative real-time RT-PCR.

\begin{tabular}{llc}
\hline Gene & \multicolumn{1}{c}{ Primer } & UPL probe \\
\hline GAPDH (NM_002046.3) & 5'-AGCCACATCGCTCAGACAC-3' & 60 \\
& 5'-GCCCAATACGACCAAATCC-3' & 27 \\
ENO2 (NM_001975.2) & 5'-ACTTTGTCAGGGACTATCCTGTG-3' & \\
AXIN2 (NM_004655.3) & 5'-TCCCTACATTGGCTGTGAACT-3' & 88 \\
& 5'-AGAGCAGCTCAGCAAAAAGG-3' & \\
\hline
\end{tabular}

6 female and 14 male, 14 normal mucosa, 3 adenoma and 3 T1 CRC tissues) after informed consent from Osaka University Medical Hospital with approval of the Research Ethics Board. Normal intestinal epithelia were collected from patients without evidence of symptomatic or microscopic inflammation, and distance of $>3 \mathrm{~cm}$ to the tumors.

Histopathology, immunohistochemical and immunofluorescent analyses of intestinal tissue. Human colorectal tissue was fixed in $10 \%$ buffered formalin and embedded in paraffin. Sequential 5- $\mu \mathrm{m}$ sections were stained with hematoxylin and eosin (H\&E) for histopathological analyses, and for immunohistological analyses with antibodies to CA9 (2D3, 1:500; Abcam, Cambridge, MA, USA and EPR4151, 1:200; Epitomics, Burlingame, CA, USA), neuron specific enolase (NSE) (1:100; Assaybiotech, Sunnyvale, CA, USA), CD68 (PG-M1; Dako, Carpinteria, CA, USA) and polypyrimidine tract-binding protein 1 (PTBP1) $(\mathrm{M} 01,3 \mu \mathrm{g} / \mathrm{ml}$; Abnova, Taipei, Taiwan). Antigen retrieval (10 mmol/l citrate buffer, $\mathrm{pH} 6$ at $100^{\circ} \mathrm{C}$ for $40 \mathrm{~min}$ ) was performed on paraffinembedded tissues. Visualization was performed using either fluorescent-conjugated species-specific secondary antibodies or the avidin-biotin-peroxidase method (Vectastain Elite ABC reagent kit; Vector Laboratories, Burlingame, CA, USA). Nuclear counterstaining was performed with hematoxylin or ProLong Gold antifade reagent with DAPI (Invitrogen, Carlsbad, CA, USA). All-in-one type fluorescence microscopy (BZ-8000; Keyence, Osaka, Japan) with digital photographic capability was used to visualize cells at several magnifications.

Calculation of the frequency of $\mathrm{CA}^{+}$cells of the intestinal crypts. The frequency of CA $9^{+}$cells at specific positions relative to the crypt bottom were evaluated using crypts which intact overall longitudinal sections were available in sections of immunohistochemical staining with anti-CA9 antibody. The counting of intestinal epithelial $\mathrm{CA} 9^{+}$and $\mathrm{CA} 9^{-}$cells was performed three times independently using 20, 70 and 150 crypts for ileum, right colon and left colon, respectively. The frequency of $\mathrm{CA} 9^{+}$cells was calculated by the ratio of the total number of $\mathrm{CA}^{+}$cells to the total number of $\mathrm{CA}^{-}$and CA9 ${ }^{+}$cells at each cell position relative to crypt bottom.

Crypt isolation and cell dissociation. The intestinal tissues were washed with cold phosphate-buffered saline (PBS) until the supernatant was clear. Next, they were incubated in $8 \mathrm{mmol} / \mathrm{l}$ ethylenediaminetetraacetic acid (EDTA) cold chelation buffer (distilled water with $5.6 \mathrm{mmol} / 1 \mathrm{Na}_{2} \mathrm{HPO}_{4}, 8.0 \mathrm{mmol} / 1 \mathrm{KH}_{2} \mathrm{PO}_{4}$,
$96.2 \mathrm{mmol} / 1 \mathrm{NaCl}, 1.6 \mathrm{mmol} / \mathrm{K} \mathrm{KCl}, 43.4 \mathrm{mmol} / 1$ sucrose, $54.9 \mathrm{mmol} / 1 \mathrm{D}$-sorbitol, $0.5 \mathrm{mmol} / \mathrm{l} \mathrm{DL}$-dithiothreitol) (20) for $10 \mathrm{~min}$ on ice and the intestinal crypts were stripped and collected with angled Debakey forceps under a stereomicroscope (SZX10; Olympus, Tokyo, Japan). After washing with cold chelation buffer, the isolated crypts were incubated with TrypLE Express (Invitrogen) including 2,000 U/ml DNase (Sigma-Aldrich, St. Louis, MO, USA) for $60 \mathrm{~min}$ at $37^{\circ} \mathrm{C}$, passed through $40 \mu \mathrm{m}$ cell strainers, treated with BD Pharm Lyse (BD Biosciences, San Jose, CA, USA) for the lysis of red blood cells and then washed with cold chelation buffer.

Flow cytometry. Dissociated intestinal crypt cells were blocked with FcR blocking reagent (BD Biosciences) and incubated with antibodies as follows; anti-human CA9 (APC-conjugated; R\&D Systems, Minneapolis, MN, USA), anti-human CD31 (FITC-conjugated; eBiosciences, San Diego, CA, USA), antihuman CD44 (PE-conjugated) and lineage cocktail 1 (Lin1) (FITC-conjugated) (both from BD Biosciences). 7-AAD (BD Biosciences) was used to eliminate dead cells. Cells were analyzed and isolated by using FACSAria II equipped with FACSDiva software (BD Biosciences). The live single epithelial crypt base cells $(21,22)\left(7-\mathrm{AAD}^{-/ \mathrm{CD}} 31^{-} / \mathrm{Lin}^{-} / \mathrm{CD} 44^{+}\right)$ were evaluated for the CA9 expression and sorted accordingly.

$R N A$ preparation and quantitative real-time-polymerase chain reaction ( $q R T-P C R)$. Total RNA was isolated using TRIzol reagent (Invitrogen). In all cases, $400 \mathrm{ng}$ of total RNA was reverse-transcribed with High Capacity RNA-to-cDNA Master Mix (Applied Biosystems, Foster City, CA, USA) following the manufacturer's instructions. For quantitative assessments, quantitative real-time reverse transcriptase analysis was performed with the LightCycler TaqMan master kit (Roche Diagnostics, Tokyo, Japan) and the LightCycler 480 system (Roche Applied Science, Indianapolis, IN, USA). Primers are listed in Table I.

Statistical analysis. The relationships among gene expressions, cell counts, and tumor volume were analyzed using ANOVA. All tests were analyzed with GraphPad Prism 6 software (GraphPad Software, San Diego, CA, USA). A value of $\mathrm{P}<0.05$ was taken as statistically significant.

\section{Results}

CA9 protein expression in human intestinal crypt base. To assess anatomical pattern of CA9 expression in human normal 

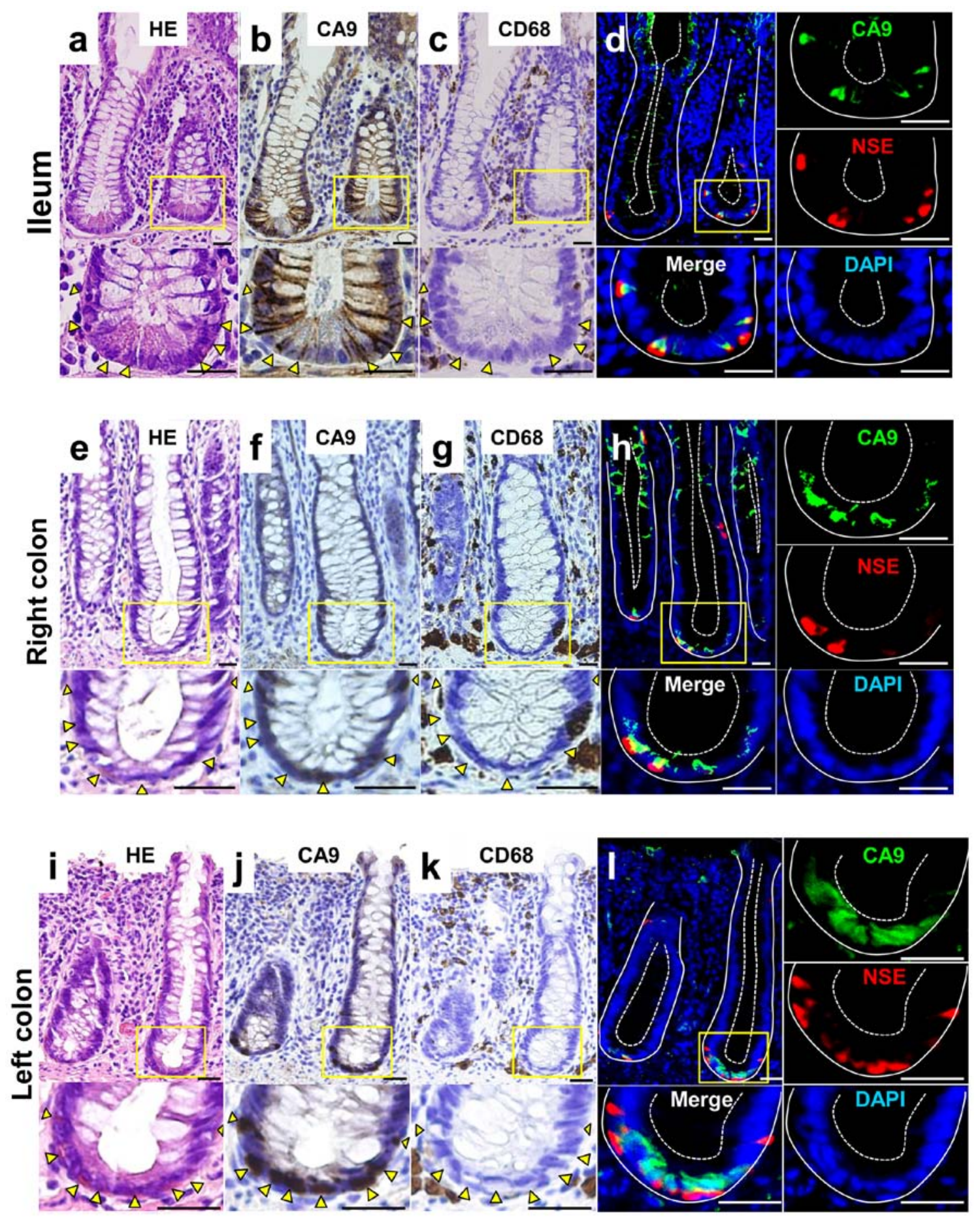

Figure 1. CA9 expression pattern in the human ileum and colon. Representative staining patterns of human ileum (a-d), right colon (e-h) and left colon (i-1). (a,e and i) Hematoxylin and eosin (H\&E) staining. (b, f and j) Immunohistochemical (IHC) staining with anti-CA9 antibody. (c, g and k) IHC staining with antiCD68, a macrophage marker. (d, h and 1) Immunofluorescent staining with antibodies to CA9 (green), neuron specific enolase (NSE) (red) and counterstained with DAPI (blue). Larger magnification views of the crypt base boxed in yellow are shown at the bottom on the right. IHC staining sections were visualized with diaminobenzidine (brown) and counterstained with hematoxylin. Arrowheads point to cells which express CA9. White solid lines demarcate epithelialmesenchymal boundary, and dashed lines mark the apical epithelial surface in (d, h and 1). Scale bar, $25 \mu \mathrm{m}$. Original magnification, top, x20; bottom, x40.

intestinal epithelia, formalin-fixed paraffin-embedded serial sections of ileum, right colon and left colon were stained with H\&E, CA9, CD68 and NSE (Fig. 1). The CA9 expression was confined to cell membrane and was mainly observed in slender cells at the bottom of small intestinal and in colon crypts with mosaic pattern. CA9 ${ }^{+}$cells commonly contained eosinophilic structure in basal cytoplasm. Among those evaluated, none of the $\mathrm{CA} 9^{+}$cells located in the intestinal epithelia were positive for CD68, a marker for macrophage, which means that although intestinal lamina propria contains abundant macrophages (23), macrophages were not the source of $\mathrm{CA} 9^{+}$cells. Almost all of the $\mathrm{CA} 9^{+}$cells in the crypt base were also stained with NSE.

Frequency of $\mathrm{CA}^{+}$intestinal epithelial cells in association with their position. To quantify the frequency of the CA9+ intestinal epithelial cells in association with their position 

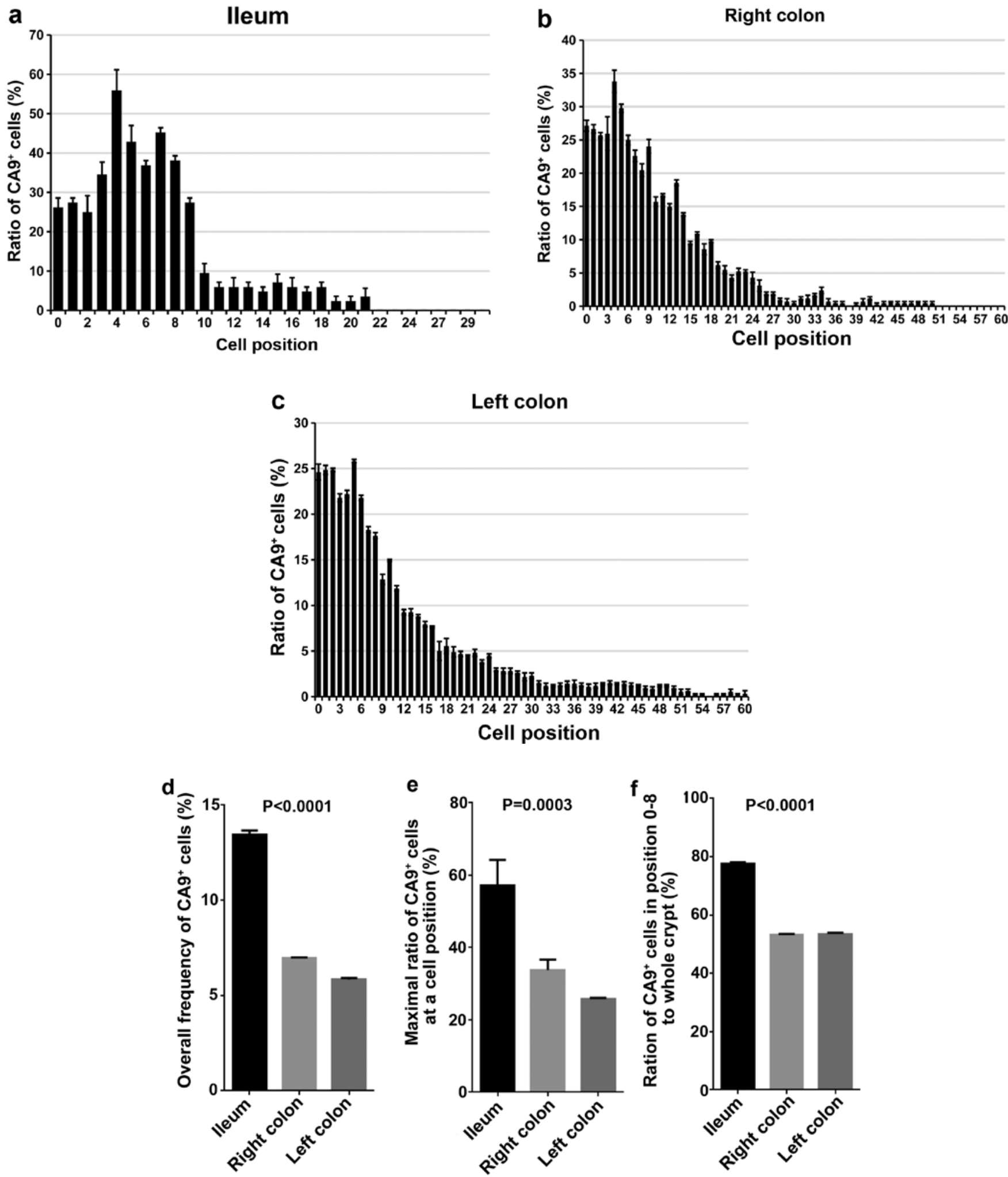

Figure 2. The frequency of CA $9^{+}$cells in the human ileum and colon. The frequency of CA $9^{+}$cells appeared at specific positions relative to the crypt bottom in human ileum (a), right colon (b) and left colon (c). The overall frequency of $\mathrm{CA} 9^{+}(\mathrm{d})$, maximal frequency of CA $9^{+}$cells at a position (e) and the ratio of $\mathrm{CA} 9^{+}$ cells located in crypt base region (f) in ileum, right colon and left colon. Most of the CA9 $9^{+}$cells were found to be almost alternately positioned at the base of crypts, and rarely found in distal positions.

relative to crypt bottom, the counting of $\mathrm{CA} 9^{-}$and $\mathrm{CA} 9^{+}$cells of intestinal epithelia in ileum, right colon and left colon was performed (Fig. 2a-c). Total frequency of CA9 ${ }^{+}$cells was $13.5 \pm 0.2,7.0 \pm 0.1$ and $5.9 \pm 0.1 \%$, the maximal frequency of CA $9^{+}$cells in relation to cell position was $56.0 \pm 9.0 \%$ (cell position 3), $33.8 \pm 2.9 \%$ (cell position 4), $25.8 \pm 0.3 \%$ (cell position 5) and the ratio of CA9 $9^{+}$cells in crypt base (cell position $0-8$ ) was $77.7 \pm 0.5,53.1 \pm 0.4$ and $53.5 \pm 0.4$ in ileum, right colon and left colon, respectively (Fig. 2d-f). These data indicate that $\mathrm{CA}^{+}$cells are mainly located in the crypt base, 

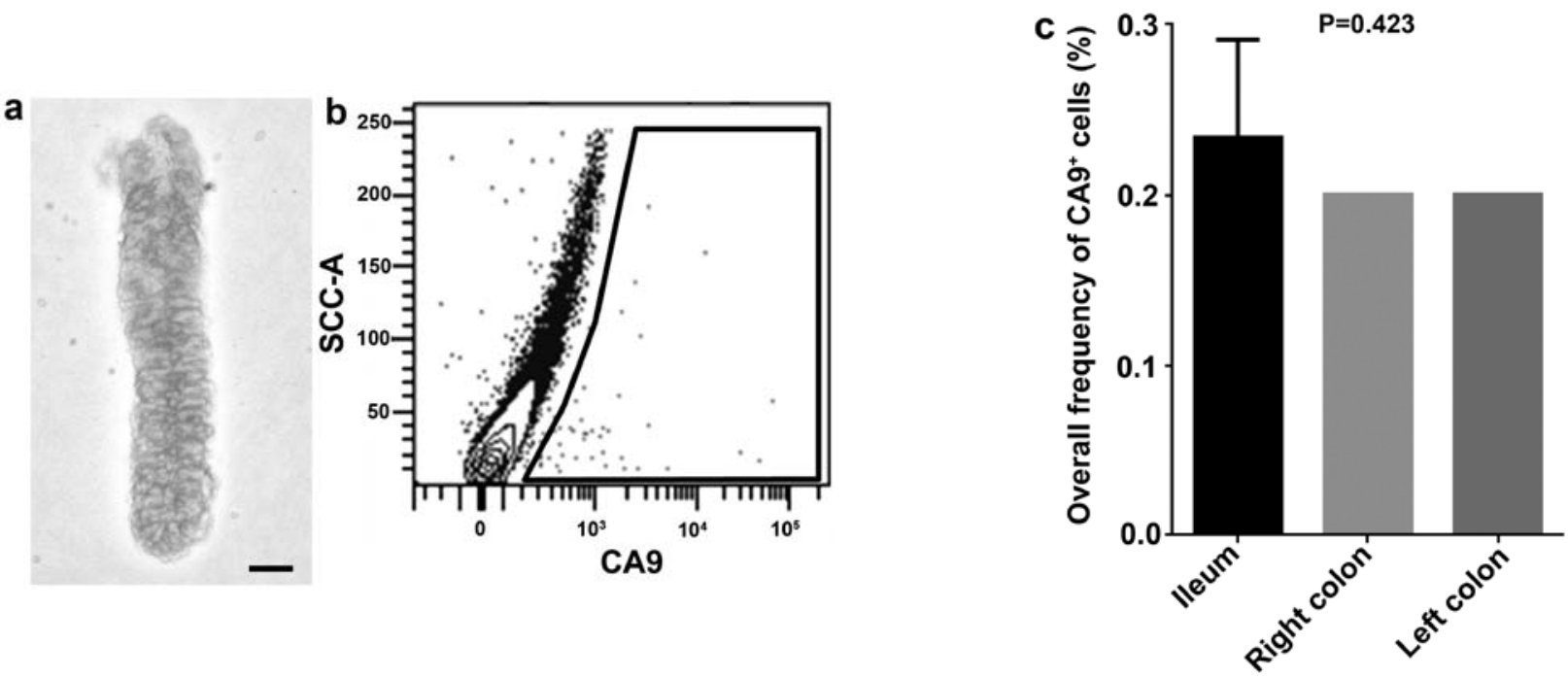

Figure 3. Flow cytometry analysis of human intestinal epithelia with CA9. (a) Representative image of an isolated intestinal epithelial crypt. (b) Representative dot plots of human CRC cell lines incubated with an anti-CA9 antibody. (c) Frequency of CA9+ cells detected by flow cytometry in ileum, right colon and left colon. Scale bar, $25 \mu \mathrm{m}$. The frequency of $\mathrm{CA} 9^{+}$cells was smaller than that of IHC.

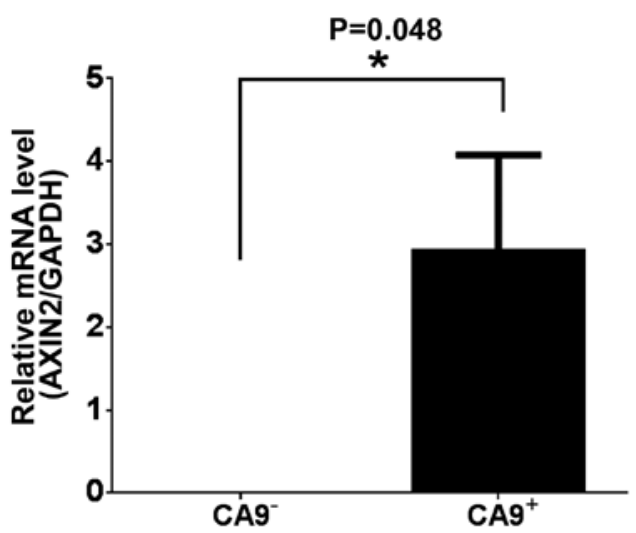

Figure 4. Comparison of the expression of AXIN2 in CA9- and CA9 $9^{+}$human intestinal epithelial cells. The expression of AXIN2, a Wnt pathway-associated gene, was evaluated by the ratio normalized to GAPDH expression in human intestinal epithelial CA9- and CA9 $9^{+}$cells as determined by qRT-PCR $\mathrm{CA} 9^{+}$cells showed significantly higher level of AXIN2 than CA9- cells.

and ileum contains more $\mathrm{CA}^{+}$cells in the crypt base than right or left colon.

CA9 $9^{+}$intestinal epithelial cells in fresh human clinical samples. To investigate the biological function of $\mathrm{CA} 9^{+}$cells in intestinal epithelial crypt base, flow cytometric analysis was performed on freshly isolated human intestinal epithelial cells. The percentage of $\mathrm{CA}^{+}$cells was $0.23 \pm 0.06,0.20 \pm 0.00$ and $0.20 \pm 0.00 \%$, in ileum, right colon and left colon, respectively, without significant difference among the locations ( $\mathrm{P}=0.4226)$ (Fig. 3).

Correlation of CA9 and the Wht pathway gene AXIN2. To elucidate the characteristic of the $\mathrm{CA}^{+}$cells in intestinal epithelial cells, expression of $A X I N 2$, a direct target gene of Wnt pathway (24), was analyzed on freshly isolated CA9and $\mathrm{CA}^{+}$dissociated human intestinal epithelial cells by qRT-PCR. The expression of AXIN2 in $\mathrm{CA}^{+}$cell population was significantly higher than that of $\mathrm{CA}^{-}(\mathrm{P}=0.048)$ (Fig. 4).
CA9 protein expression in adenoma and T1 CRC. To investigate the relationship between CA9 expression and tumorigenesis, formalin-fixed paraffin-embedded sections were stained with CA9 in adenoma (3 samples) and T1 CRC (3 samples). Three (100\%) and $3(100 \%)$ were positive for CA9 in adenoma and T1 CRC, respectively. In adenomas, the CA9 expression was confined to cell membrane and was observed with mosaic-like pattern at the bottom of crypt-like structures where PTBP1, a hypoxia-related protein (25), is abundantly observed (Fig. 5a and c). In T1 cancer, CA9 expression was also confined to cell membrane but almost all cells were positive for CA9, and there was no apparent difference of staining positivity in the same tumor tissue (Fig. $5 b$ and d).

\section{Discussion}

In this study, we precisely revealed that $\mathrm{CA} 9^{+}$cells exist in human adult crypt base of ileum, right colon and left colon epithelia, and we also showed that the CA9 $9^{+}$cells in the crypt base are suspected to be associated with intestinal stem cells morphologically and functionally. We also showed possible association of CA9 expression with carcinogenesis.

In human adult normal intestinal epithelial crypt, $\mathrm{CA} 9^{+}$cells were slender and mainly distributed with mosaic pattern, which is consistent with morphological characteristic of previously reported intestinal epithelial stem cells (2-8). It is noteworthy that the CA9 expressed in normal colorectal epithelia is reported to be a splicing variant lacking $\mathrm{C}$-terminal part of the catalytic domain and it is different from the full-length form expressed in CRC and increased by hypoxia (26). This may explain the reason $\mathrm{CA} 9^{+}$cells are arranged in intestinal crypt bases with mosaic pattern regardless of the distance from blood vessels. The antibodies, which we used in this study, can also used in flow cytometry under non-denatered condition. Since the reported splicing variant of CA9 is lacking trans-membranous domain, the C-terminal of the full-length protein, the CA9 protein levels which we analyzed in this study contains both forms of CA9. Although NSE is commonly considered 

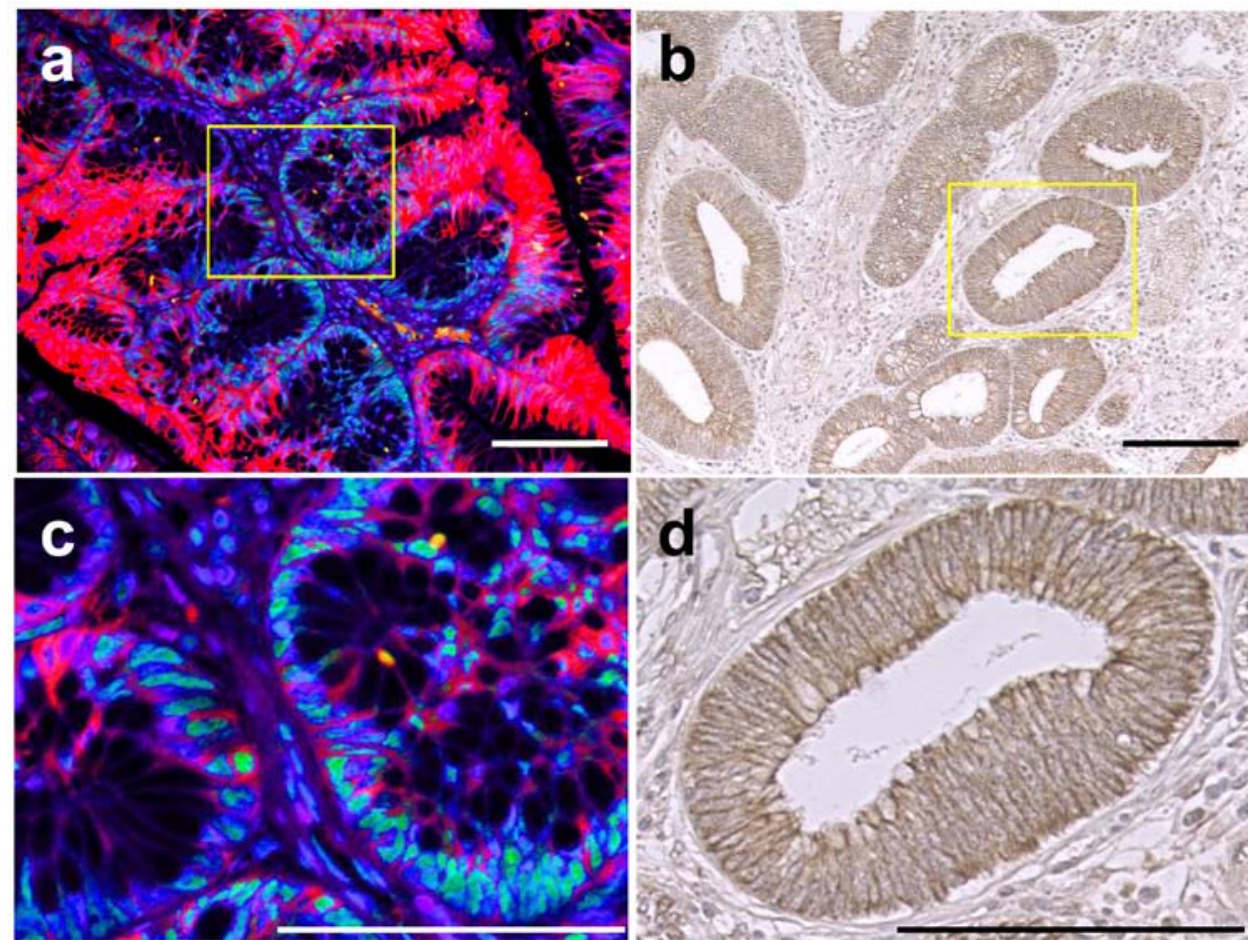

Figure 5. CA9 expression pattern in adenoma and T1 colorectal cancer tissue. (a and c) Immunofluorescent-staining merged images of tubular adenoma with antibodies to CA9 (red), polypyrimidine tract-binding protein (PTBP1) (green) and counterstained with DAPI (blue). (b and d) IHC staining images of T1 adenocarcinoma with anti-CA9 antibody, visualized with diaminobenzidine (brown) and counterstained with hematoxylin. Larger magnification views of the typically stained pattern boxed in yellow (a and b) are shown (c and d). Scale bar, $100 \mu \mathrm{m}$. Original magnification (a and b) x20; (c and d), x40.

to be a marker for enteroendocrine cells $(27,28)$, intestinal quiescent stem cells were recently shown to be the precursors which were committed to mature into differentiated secretory cells of the Paneth and enteroendocrine lineage (29). In addition, NSE functions as a glycolytic enzyme by converting 2-phospho-D-glycerate into phosphoenolpyruvate and exhibits proliferative and protective effects on cultured neuron cells (30). These facts imply that it is reasonable for the morphologically stem-like cells in the intestinal crypt base to express NSE in this study. It was notable that $\mathrm{CA} 9^{+}$cells in crypt base expressed $A X I N 2$, a direct target gene of Wnt pathway (24), which indicates that they have increased activity of Wnt pathway, a critical pathway for intestinal epithelial stem cells (2). Based on these findings, it can be supposed that the $\mathrm{CA} 9^{+}$cells in human adult normal intestinal epithelia are associated with stemness, although CA9 has been associated with hypoxia in embryonic and fetal intestinal epithelia (14), and CA9 per se is not imperative in the development or maintenance of intestinal epithelia under normal condition (31).

In the process of carcinogenesis and progression, cancer cells are required to overcome hypoxia and acidosis caused by over-population and increased distance from blood vessels (32). CA9 is induced by hypoxia (33-35) and regulates $\mathrm{pH}$ of microenvironment (36). In addition, CA9 has been shown to support carcinogenesis itself, promote cell migration, invasion angiogenesis and metastasis (37-41) and to be associated with cancer stemness (42) and resistance to the therapies (41-44). All these aspects are consistent with our results yielded from clinical samples and data, where the expression of CA9 is mostly associated with poor prognosis or progressed stage (16-19,44-49). In this study, we showed that the colorectal adenomas had mosaic pattern of CA9 expression in basal region, similar to but more aberrant than normal epithelia, and that T1 CRC had CA9 expression in entire area of the tumor, contrary to the normal intestinal epithelia which $\mathrm{CA}^{+}$ratio is as low as $10 \%$. Thus, it could be reasonable to suspect that the $\mathrm{CA} 9^{+}$cells are associated with carcinogenesis.

This study have some limitations as follows. First, we analyzed the $\mathrm{CA} 9^{+}$cells only in immunohistrochemistry and flow cytometry. In addition, analyzed sample number is small for reading strong evidence. Second, although the morphology of $\mathrm{CA} 9^{+}$cells were same as the CBC cells which were reported as the stem cells of mouse small intestine, there has not been any evidence that the same event was also justified in human samples. Third, although there was a gap of the ratio of $\mathrm{CA}^{+}$cells among the anatomical location, we were unable to explain its meaning. The gaps of the ratio of CA9 ${ }^{+}$cells between IHC and flow cytometry may be explained by the fact that the sensitivity of the antibodies used for flow cytometry and those for IHC was different (50) and that the methodology of calculation of positivity was two-dimensional in IHC and three-dimensional in flow cytometry. Forth, although in flow cytometry, we could detect CA9 high cells in mucosal epithelial cells, in immunohistochemistry, we could not classify the epithelial cells according to CA9 staining intensity. However, accoding to Fig. 1b, epithelial cells on villi were weakly positive and CBC cells were highly positive for CA9 suggesting that $\mathrm{CA} 9^{+}$cells would be morphologically identical for $\mathrm{CBC}$ cells. Further studies would be needed for understanding the CA9 fuctions. This study propose the possibility that CA9 could be a new marker of human adult intestinal epithelial stem cells and that it is associated with carcinogenesis in CRC. 


\section{Acknowledgements}

This study was supported by a Grant-in-Aid for Cancer Research from the Ministry of Education, Science, Sports and Culture Technology, Japan, to H.Y. (grant no. 21390360).

\section{References}

1. Cheng $\mathrm{H}$ and Leblond CP: Origin, differentiation and renewal of the four main epithelial cell types in the mouse small intestine. V. Unitarian Theory of the origin of the four epithelial cell types. Am J Anat 141: 537-561, 1974.

2. Barker N, van Es JH, Kuipers J, Kujala P, van den Born M, Cozijnsen M, Haegebarth A, Korving J, Begthel H, Peters PJ, et al: Identification of stem cells in small intestine and colon by marker gene Lgr5. Nature 449: 1003-1007, 2007.

3. Potten CS: Extreme sensitivity of some intestinal crypt cells to $X$ and gamma irradiation. Nature 269: 518-521, 1977.

4. Sangiorgi E and Capecchi MR: Bmil is expressed in vivo in intestinal stem cells. Nat Genet 40: 915-920, 2008.

5. Takeda N, Jain R, LeBoeuf MR, Wang Q, Lu MM and Epstein JA Interconversion between intestinal stem cell populations in distinct niches. Science 334: 1420-1424, 2011.

6. Montgomery RK, Carlone DL, Richmond CA, Farilla L, Kranendonk ME, Henderson DE, Baffour-Awuah NY, Ambruzs DM, Fogli LK, Algra S, et al: Mouse telomerase reverse transcriptase (mTert) expression marks slowly cycling intestinal stem cells. Proc Natl Acad Sci USA 108: 179-184, 2011.

7. Powell AE, Wang Y, Li Y, Poulin EJ, Means AL, Washington MK, Higginbotham JN, Juchheim A, Prasad N, Levy SE, et al: The pan-ErbB negative regulator Lrig1 is an intestinal stem cell marker that functions as a tumor suppressor. Cell 149: 146-158, 2012.

8. Sato T, van Es JH, Snippert HJ, Stange DE, Vries RG, van den Born M, Barker N, Shroyer NF, van de Wetering M and Clevers H: Paneth cells constitute the niche for Lgr5 stem cells in intestinal crypts. Nature 469: 415-418, 2011.

9. Korinek V, Barker N, Moerer P, van Donselaar E, Huls G, Peters PJ and Clevers H: Depletion of epithelial stem-cell compartments in the small intestine of mice lacking Tcf-4. Nat Genet 19: 379-383, 1998 .

10. Pellegrinet L, Rodilla V, Liu Z, Chen S, Koch U, Espinosa L, Kaestner KH,Kopan R, Lewis J, Radtke F: Dll1- and dll4-mediated notch signaling are required for homeostasis of intestinal stem cells. Gastroenterology 140: 1230-1240 e1231-1237, 2011.

11. Sato T, Vries RG, Snippert HJ, van de Wetering M, Barker N, Stange DE, van Es JH, Abo A, Kujala P, Peters PJ, et al: Single Lgr5 stem cells build crypt-villus structures in vitro without a mesenchymal niche. Nature 459: 262-265, 2009.

12. Haramis AP, Begthel H, van den Born M, van Es J, Jonkheer S, Offerhaus GJ and Clevers H: De novo crypt formation and juvenile polyposis on BMP inhibition in mouse intestine. Science 303: 1684-1686, 2004.

13. Ivanov S, Liao SY, Ivanova A, Danilkovitch-Miagkova A, Tarasova N, Weirich G, Merrill MJ, Proescholdt MA, Oldfield EH, Lee J, et al: Expression of hypoxia-inducible cell-surface transmembrane carbonic anhydrases in human cancer. Am J Pathol 158: 905-919, 2001.

14. Liao SY, Lerman MI and Stanbridge EJ: Expression of transmembrane carbonic anhydrases, CAIX and CAXII, in human development. BMC Dev Biol 9: 22, 2009.

15. Hussain SA, Ganesan R, Reynolds G, Gross L, Stevens A, Pastorek J, Murray PG, Perunovic B, Anwar MS, Billingham L, et al: Hypoxia-regulated carbonic anhydrase IX expression is associated with poor survival in patients with invasive breast cancer. Br J Cancer 96: 104-109, 2007.

16. Ilie M, Mazure NM, Hofman V, Ammadi RE, Ortholan C, Bonnetaud C, Havet K, Venissac N, Mograbi B, Mouroux J, et al: High levels of carbonic anhydrase IX in tumour tissue and plasma are biomarkers of poor prognostic in patients with non-small cell lung cancer. Br J Cancer 102: 1627-1635, 2010.

17. Saarnio J, Parkkila S, Parkkila AK, Haukipuro K, Pastoreková S, Pastorek J, Kairaluoma MI and Karttunen TJ: Immunohistochemical study of colorectal tumors for expression of a novel transmembrane carbonic anhydrase, MN/CA IX, with potential value as a marker of cell proliferation. Am J Pathol 153: $279-285,1998$
18. Jubb AM, Turley H, Moeller HC, Steers G, Han C, Li JL, Leek R, Tan EY, Singh B, Mortensen NJ, et al: Expression of delta-like ligand 4 (Dll4) and markers of hypoxia in colon cancer. Br J Cancer 101: 1749-1757, 2009.

19. Korkeila E, Talvinen K, Jaakkola PM, Minn H, Syrjänen K, Sundström J and Pyrhönen S: Expression of carbonic anhydrase IX suggests poor outcome in rectal cancer. Br J Cancer 100: 874-880, 2009.

20. Sato T, Stange DE, Ferrante M, Vries RG, Van Es JH, Van den Brink S, Van Houdt WJ, Pronk A, Van Gorp J, Siersema PD, et al: Long-term expansion of epithelial organoids from human colon, adenoma, adenocarcinoma, and Barrett's epithelium. Gastroenterology 141: 1762-1772, 2011.

21. Rothenberg ME, Nusse Y,Kalisky T,Lee JJ, Dalerba P, ScheerenF, Lobo N, Kulkarni S, Sim S, Qian D, et al: Identification of a cKit(+) colonic crypt base secretory cell that supports Lgr5(+) stem cells in mice. Gastroenterology 142: 1195-1205 e1196, 2012.

22. Gracz AD, Fuller MK, Wang F, Li L, Stelzner M, Dunn JC, Martin MG and Magness ST: Brief report: CD24 and CD44 mark human intestinal epithelial cell populations with characteristics of active and facultative stem cells. Stem Cells 31: 2024-2030, 2013.

23. Smith PD, Smythies LE, Shen R, Greenwell-Wild T, Gliozzi M and Wahl SM: Intestinal macrophages and response to microbial encroachment. Mucosal Immunol 4: 31-42, 2011.

24. Jho EH, Zhang T, Domon C, Joo CK, Freund JN and Costantini F: Wnt/beta-catenin/Tcf signaling induces the transcription of Axin2, a negative regulator of the signaling pathway. Mol Cell Biol 22: 1172-1183, 2002.

25. Kang K, Peng X, Zhang X, Wang Y, Zhang L, Gao L, Weng T, Zhang H, Ramchandran R, Raj JU, et al: MicroRNA-124 suppresses the transactivation of nuclear factor of activated $\mathrm{T}$ cells by targeting multiple genes and inhibits the proliferation of pulmonary artery smooth muscle cells. J Biol Chem 288: 25414-25427, 2013

26. Barathova M, Takacova M, Holotnakova T, Gibadulinova A, Ohradanova A, Zatovicova M, Hulikova A, Kopacek J, Parkkila S, Supuran CT, et al: Alternative splicing variant of the hypoxia marker carbonic anhydrase IX expressed independently of hypoxia and tumour phenotype. Br J Cancer 98: 129-136, 2008.

27. Radu I: Morphological aspects of endocrine cells in human fetal gastrointestinal mucosa. Microscopical, electronmicroscopical and immunohistochemical studies. Rom J Morphol Embryol 40: 93-98, 1994.

28. Rindi G, Leiter AB, Kopin AS, Bordi C and Solcia E: The 'normal' endocrine cell of the gut: Changing concepts and new evidences. Ann NY Acad Sci 1014: 1-12, 2004.

29. Buczacki SJ, Zecchini HI, Nicholson AM, Russell R, Vermeulen L, Kemp R and Winton DJ: Intestinal label-retaining cells are secretory precursors expressing Lgr5. Nature 495: 65-69, 2013.

30. Hattori T, Takei N, Mizuno Y, Kato K and Kohsaka S: Neurotrophic and neuroprotective effects of neuron-specific enolase on cultured neurons from embryonic rat brain. Neurosci Res 21: 191-198, 1995.

31. Leppilampi M, Karttunen TJ, Kivelä J, Gut MO, Pastoreková S, Pastorek J and Parkkila S: Gastric pit cell hyperplasia and glandular atrophy in carbonic anhydrase IX knockout mice: Studies on two strains C57/BL6 and BALB/C. Transgenic Res 14: 655-663, 2005.

32. Gatenby RA and Gillies RJ: A microenvironmental model of carcinogenesis. Nat Rev Cancer 8: 56-61, 2008.

33. Wykoff CC, Beasley NJ, Watson PH, Turner KJ, Pastorek J, Sibtain A, Wilson GD, Turley H, Talks KL, Maxwell PH, et al: Hypoxia-inducible expression of tumor-associated carbonic anhydrases. Cancer Res 60: 7075-7083, 2000.

34. Kaluz S, Kaluzová M, Chrastina A, Olive PL, Pastoreková S, Pastorek J, Lerman MI and Stanbridge EJ: Lowered oxygen tension induces expression of the hypoxia marker MN/carbonic anhydrase IX in the absence of hypoxia-inducible factor 1 alpha stabilization: A role for phosphatidylinositol 3'-kinase. Cancer Res 62: 4469-4477, 2002.

35. Kaluz S, Kaluzová M and Stanbridge EJ: Expression of the hypoxia marker carbonic anhydrase IX is critically dependent on SP1 activity. Identification of a novel type of hypoxia-responsive enhancer. Cancer Res 63: 917-922, 2003.

36. Swietach P, Hulikova A, Vaughan-Jones RD and Harris AL: New insights into the physiological role of carbonic anhydrase IX in tumour $\mathrm{pH}$ regulation. Oncogene 29: 6509-6521, 2010. 
37. Kim BR, Shin HJ, Kim JY, Byun HJ, Lee JH, Sung YK and Rho SB: Dickkopf-1 (DKK-1) interrupts FAK/PI3K/mTOR pathway by interaction of carbonic anhydrase IX (CA9) in tumorigenesis. Cell Signal 24: 1406-1413, 2012.

38. Rasheed S, Harris AL, Tekkis PP, Turley H, Silver A, McDonald PJ, Talbot IC, Glynne-Jones R, Northover JM and Guenther T: Assessment of microvessel density and carbonic anhydrase-9 (CA-9) expression in rectal cancer. Pathol Res Pract 205: 1-9, 2009.

39. Svastová E, Zilka N, Zat'ovicová M, Gibadulinová A, Ciampor F, Pastorek $\mathrm{J}$ and Pastoreková S: Carbonic anhydrase IX reduces E-cadherin-mediated adhesion of MDCK cells via interaction with beta-catenin. Exp Cell Res 290: 332-345, 2003.

40. Shin HJ, Rho SB, Jung DC, Han IO, Oh ES and Kim JY: Carbonic anhydrase IX (CA9) modulates tumor-associated cell migration and invasion. J Cell Sci 124: 1077-1087, 2011.

41. Lou Y, McDonald PC, Oloumi A, Chia S, Ostlund C, Ahmadi A, Kyle A, Auf dem Keller U, Leung S, Huntsman D, et al: Targeting tumor hypoxia: Suppression of breast tumor growth and metastasis by novel carbonic anhydrase IX inhibitors. Cancer Res 71: 3364-3376, 2011.

42. Lock FE, McDonald PC, Lou Y, Serrano I, Chafe SC, Ostlund C, Aparicio S, Winum JY, Supuran CT and Dedhar S: Targeting carbonic anhydrase IX depletes breast cancer stem cells within the hypoxic niche. Oncogene 32: 5210-5219, 2013.

43. Sansone P, Storci G, Tavolari S, Guarnieri T, Giovannini C, Taffurelli M, Ceccarelli C, Santini D, Paterini P, Marcu KB, et al: IL-6 triggers malignant features in mammospheres from human ductal breast carcinoma and normal mammary gland. J Clin Invest 117: 3988-4002, 2007.

44. Proescholdt MA, Merrill MJ, Stoerr EM, Lohmeier A, Pohl F and Brawanski A: Function of carbonic anhydrase IX in glioblastoma multiforme. Neuro Oncol 14: 1357-1366, 2012.
45. Chia SK, Wykoff CC, Watson PH, Han C, Leek RD, Pastorek J, Gatter KC, Ratcliffe P and Harris AL: Prognostic significance of a novel hypoxia-regulated marker, carbonic anhydrase IX, in invasive breast carcinoma. J Clin Oncol 19: 3660-3668, 2001.

46. Driessen A, Landuyt W, Pastorekova S, Moons J, Goethals L, Haustermans K, Nafteux P, Penninckx F, Geboes K, Lerut T, et al: Expression of carbonic anhydrase IX (CA IX), a hypoxiarelated protein, rather than vascular-endothelial growth factor (VEGF), a pro-angiogenic factor, correlates with an extremely poor prognosis in esophageal and gastric adenocarcinomas. Ann Surg 243: 334-340, 2006.

47. Bui MH, Seligson D, Han KR, Pantuck AJ, Dorey FJ, Huang Y, Horvath S, Leibovich BC, Chopra S, Liao SY, et al: Carbonic anhydrase IX is an independent predictor of survival in advanced renal clear cell carcinoma: Implications for prognosis and therapy. Clin Cancer Res 9: 802-811, 2003.

48. Malentacchi F, Vinci S, Della Melina A, Kuncova J, Villari D, Giannarini G, Nesi G, Selli C and Orlando C: Splicing variants of carbonic anhydrase IX in bladder cancer and urine sediments. Urol Oncol 30: 278-284, 2012.

49. Beasley NJ, Wykoff CC, Watson PH, Leek R, Turley H, Gatter K, Pastorek J, Cox GJ, Ratcliffe P and Harris AL: Carbonic anhydrase IX, an endogenous hypoxia marker, expression in head and neck squamous cell carcinoma and its relationship to hypoxia, necrosis, and microvessel density. Cancer Res 61: 5262-5267, 2001

50. Tokunaga T, Tomita A, Sugimoto K, Shimada K, Iriyama C, Hirose T, Shirahata-Adachi M, Suzuki Y, Mizuno H, Kiyoi H, et al: De novo diffuse large B-cell lymphoma with a CD20 immunohistochemistry-positive and flow cytometry-negative phenotype: Molecular mechanisms and correlation with rituximab sensitivity. Cancer Sci 105: 35-43, 2014. 